\title{
電動車椅子のための呼気圧によるアナログ入カインターフェース*
}

\author{
山本元 司*1 池田毅*1 \\ 佐々木 善信*2, 曹 鳳 英*3
}

\section{Analogue Input Interface for the Operation of Motored Wheelchair Using Respiratory Pressure for Severely Disabled Person}

\author{
Motoji YAMAMOTO*4, Takeshi IKEDA, \\ Yoshinobu SASAKI and Feng Yin CAO \\ ${ }^{* 4}$ Department of Mechanical Engineering, Kyushu University, \\ 744 Motooka, Nishi-ku, Fukuoka-shi, Fukuoka, 819-0395 Japan
}

\begin{abstract}
Severely handicapped often uses respiratory pressure for an input device to control various instruments such as TV, motored bed, curtain, air conditioner in everyday life. The input device is typically ON/OFF type for the control of the equipments. Considering the application of motored wheelchair, the ON/OFF type interface is not desirable. The control of motored wheelchair needs preciseness and quickness for safe operation. A new input device using respiratory pressures is proposed for such purposes. The paper examines basic performances of human respiratory pressure regulation as an analogue input method. Then possibility of two-dimensional input device is discussed. Basic experiments to check the performance of two-dimensional analogue input device by respiratory pressure for the control of motored wheelchair are shown.
\end{abstract}

Key Words: Respiratory Pressure, Analogue Input Interface, Motored Wheelchair

\section{1.はじめに}

四肢障害者のための自立支援機器として環境制御装 置 ${ }^{(1) \sim(3)}$ (テレビ, エアコン, 電動ベッド, 電話, カー テンなどを統合的に操作する装置) や電動車椅子など がある。これらの自立支援機器は障害者の残存運動機 能, 例えば口, 頭などの動きや呼気などを利用して, 生活で必要な機器を制御するものとなっている．この 研究では四肢障害者の残存運動機能を利用したユー ザーインターフェース手法について検討する.

四肢障害者用ユーザーインターフェースとしてロ， 頭などの動きを利用する場合，あるいは呼気による方 法 $^{(3)(4)}$ の場合, 従来では機器のスイッチ ON/OFFや例 えばTVチャンネル変更, 音量のステップ状の変更な ぞ，いずれも基本的にはデジ夕ル的なスイッチ操作を おこなうものとなっている，実際に利用されている機 器はこのような ON/OFF で操作可能である場合も多 い.しかしながら電動車椅子の運転などでは, 安全の ため, 素早く正確な操縦が必要であり, より良い操作 のためには連続的でなめらかな操縦が望ましい。この

*原稿受付 2008 年 6 月 23 日.

*1 正員, 九州大学大学院工学研究院機械工学部門(矛 819-0395 福岡市西区元阙 744)

*2 九州大学大学院工学㑏知能機械システム専攻.

*3 西部電機 (株) (画811-3193 古賀市駅東 3-3-1)

E-mail : yama@ mech.kyushu-u.ac.jp
ように実時間でなめらかな，すなわちアナログ情報に よる機器操作が必要な場合は，従来の ON/OFF を基 本とするインターフェースは適していないと考えられ る. 電動車椅子の場合, 通常はジョイステイックが用 いられているが，四肢等による正確なジョイスティッ ク操作が困難な場合は従来のジョイスティックをその まま用いることはできない。

電動車椅子操縱に限らず，四肢障害者が自ら様々な 機器を意のままに操作可能とするためには，残存運動 機能を十分に活用した入力インターフェースが重要と なる.この入力インターフェース手法として従来, マ イクロスイッチにより微小な力で動作可能之する方法, 舌や口でスティックを操作する方法 ${ }^{(5)}$, 皮膚表面にお ける筋電を用いる方法 ${ }^{(6)}$, 眼球, 皮膚表面, 頭部など の動きをセンサで感知する方法 ${ }^{(7)}$, 音声による入力方 法 ${ }^{(8)}$ などがある.

多くの場合，これら注基本的には ON/OFF入力に用 いられ，アナログ情報入力は困難である. また，アナ ログ入力可能な場合も実時間入力装置としては問題が あるここが多い。さらに，障害者の運動量の点で例え ば, 舌やロでスティックを操作する方法や，皮䖉表面 の動きをセンサで感知する方法は問題があり，入力装 置として精度が低い欠点がある，一方，C5〜C7 高位 での脊髄損傷の場合で, 横隔膜以外の呼吸関連筋に対 
して障害がある場合においても呼吸機能は維持できる ${ }^{(9) \sim(11)}$ ことから, 呼吸機能障害を併発していない多く の四肢障害者にも, 呼吸は意識的調整が可能な残存運 動機能と考えられる.

そこで, 筆者らは福祉機器や環境制御装置のための 大力装置として実時間のアナログ入力を可能とする装 置を考え, 呼気圧を利用するインターフェース手法を 提案している(12)(13). ここではこの呼気圧を利用する インターフェース手法により電動車椅子を操縦するこ とを想定し，アナログ呼気圧インターフェースの基本 性能を調べる. また, 安全な電動車椅子操縦のために, 入力インターフェースとしての操縦性能を高める力法 を提案しその操作性能を実験的に検証する。

\section{2. 呼気圧調整能力}

人体の呼吸運動は延䯣の呼吸中枢とよばれる部位に より，基本的には自発呼吸のリズムが呼急ニューロン 上吸息ニューロンにより自動生成されると考えられて いる(14). しかしながら, 管楽器における演奏でも明ら かなように，人は呼吸りズムを意識的に調整でき，呼 気圧值も意識的に調整可能である. この意識的調整に よる呼気压を入力インターフェース手法として利用す ることを考える. ただし, 本来のガス交換のための呼 吸は必要なため, これを阻害しないよう工夫する必要 がある。

本研究では呼気圧による入力装置としての基本的な 性能を検証するため, ディスプレイに呈示された目標 軌道に従って, 呼気圧がどの程度の性能で調整できる かを調べる：この場合の呼気圧調整は，目からの情報 が脳に伝わり，この間，調整しようとする意識ととも に何らかの情報処理がなされたのち，呼気圧調整のた めの運動制御がおこなわれると考えられる(15).このと き，ある程度先の動作が予測できる場合と，全く予測 できない場合の2つの場合では，情報処理経路やその 性能に違いがあると考えられるため，2つの場合で人 の呼気圧調整基本性能を調べる.

\section{1 呼気圧センサと実験装置 人の通常の呼気} 圧は大気相対圧で $\pm 2 \mathrm{KPa}$ 程度であるため, 呼気圧測 定のために相対圧で $\pm 5 \mathrm{KPa}$ をレンジとする微圧セン サ（フジクラ005KPGW ピエゾ抵抗型半尊体圧力セ ンサ）を使用した。このセンサは電圧出力型であり， $\mathrm{A} / \mathrm{D}$ コンバータにより圧力值を $\mathrm{PC}$ に取り込む．この センサに図 1 で示すように空圧パイプを取り付け，パ イプをロでくわえて呼気圧を調整し，この圧力を測定 する.この実験装置では, 罒に示すように比較のため にアナログジョイスティックからの電圭出力も測定で

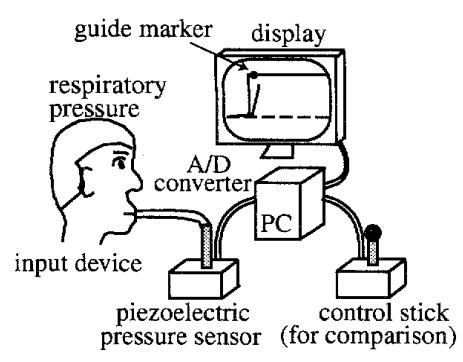

Fig. 1 Respiratory pressure response experiment

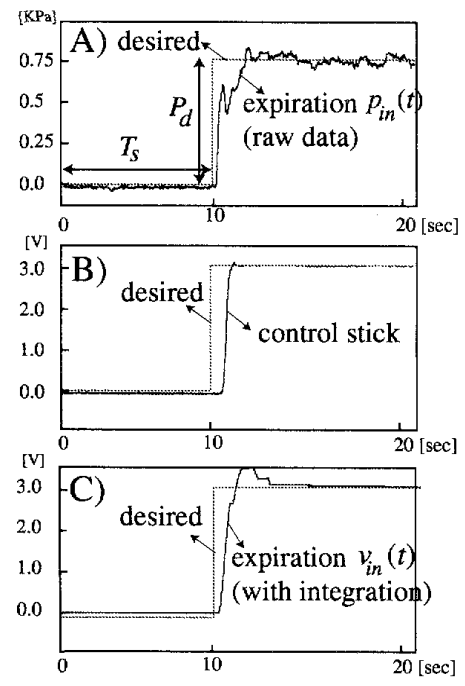

Fig. 2 Step response of expiration pressure and position of control stick

きるようにしている.

2.2 ステップ応答による呼気圧調整実験人の 呼気圧による基本的な圧力調整能力を調べる. 被験者 はディスプレイ上に現れるステップ状の目標軌道（ガ イドマーカーがこの軌道上を移動：図 1 参照）にでき るだけ正確に追従するように呼気压を調整する。

あらかじめ設定した立ち上がり時間 $T_{s}$ と目標圧力 $P_{d}$ （図 $2 \mathrm{~A}$ 参照）により，何回か練習したあとの呼気 (呼息) 圧亡手動のジョイスティック（倒し側）の典型 的な応答例を図 $2 \mathrm{~A}$, 図 $2 \mathrm{~B}$ にそれぞれ示す. 図から明 らかなように, 呼気 (呼息) 圧応答 $\mathrm{A}$ は目標值付近で 振動しており，これをそのまま入力インターフェース として用いることは困難であると考えられる.

そこで, 呼気圧值 $p_{i n}(t)$ をそのまま用いるのではな く, 次のように積分した值を応答值とし, これを調整 することを考える。

$$
v_{\text {in }}(t)=v_{0}+k_{i} \int_{0}^{t} g\left(p_{\text {in }}(t)-p_{0}\right) d t
$$




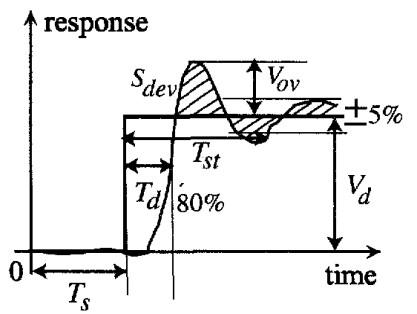

Fig. 3 Step response of respiratory pressure

$$
g(*)= \begin{cases}0 & \left(|*|<p_{\text {noise }}\right) \\ *-p_{\text {noise }} & \left(* \geq p_{\text {noise }}\right) \\ *+p_{\text {noise }} & \left(* \leq-p_{\text {noise }}\right)\end{cases}
$$

ここで $p_{i n}(t)$ は呼気圧センサからの入力, 関数 $g(*)$ は センサノイズを除去し，誤動作を防ぐための関数， $p_{0}$ は大気压， $p_{n o i s e}$ は誤動作防止のための正定数， $k_{i}$ は 積分ゲイン， $v_{0}$ は応答出力の初期值である.これによ り，ノイズの影響を軽減するとともに，入力がない場 合には応答はその值を保つことになる．このため，ガ ズ交換を維持するためにロにくわえたパイプをはずす ときは, 入力值が変動せず, 入力デバイスとして好ま しい特性を持つことになる.

式 (1)により積分したものを応答值 $v_{i n}(t)$ とし，その 応答值の調整がどの程度できるか調べた．この積分呼 気（呼息）圧值によるステップ応答例を図 $2 \mathrm{C}$ に示す. この図から明らかなように, 多少のオーバーシュート があるものの, ジョイスティックの応答図 $2 \mathrm{~B}$ と比べ同 程度の性能（精度）が得られることがわかる，呼気圧 を積分することにより，もし口から管を離しても(こ のとき $\left.p_{i n}=0\right)$ ，応答值を維持することができるため， ガス交換に必要な通常の呼吸が可能亡なる.

上記の実験ではあらかじめ設定した立ち上がり時間 $T_{s}$, 目標値 $P_{d}$ （電圧值なら $V_{d}$ ）により実験したため, 習 熟による影響が入り，呼気圧調整能力を客観的に検証 しにくい. そこで, これらの值をランダムに与え, 視 覚的なフィードバックのみに基づく人の呼気圧調整能 力を調べることにした．このとき，応答遅れ時間を $T_{d}$ (ここでは目標値の $80 \% に$ 到達した時間)，整定時間 を $T_{s t}$ (ここでは目標值の $\pm 5 \%$ 以内に整定した時間)， 最大行き過ぎ量を $V_{o v}$ とする（図 3 参照）。また，積 分呼息圧值（正圧），積分吸息圧值（負圧）の性能差 も同時に調ベた。

これらの遅れ時間 $T_{d}$, 整定時間 $T_{s t}$, 最大行き過ぎ 量 $V_{o v}$ をジョイスティックの場合（奥に倒す側十, 手前 に引く側一）と比較したものを表 1 に示す．この表中 での值は 3 名の被験者（す心゙て健常者）による 10 回 の試行の平均値である．この表から視営的なフィード
Table 1 Comparison of step responses using expiration, inspiration pressure and control stick

\begin{tabular}{c|c|c|c}
\hline & $T_{d}[\mathrm{sec}]$ & $T_{s l}[\mathrm{sec}]$ & $V_{o v}[\mathrm{~V}]$ \\
\hline respiratory(+) & 1.62 & 3.14 & 0.134 \\
respiratory(-) & 2.29 & 3.48 & 0.125 \\
control stick (+) & 0.92 & 1.82 & 0.047 \\
control stick (-) & 0.94 & 1.91 & 0.049 \\
\hline
\end{tabular}

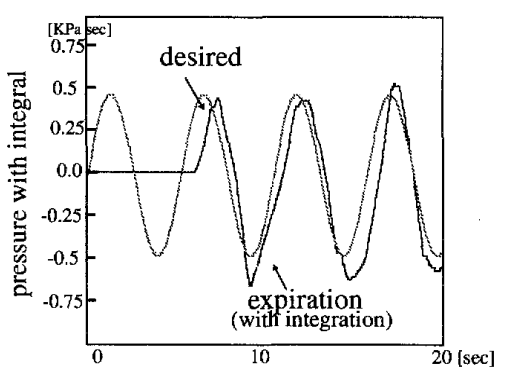

Fig. 4 Response of respiratory pressure for sine curve

バックのみによる呼気圧調整能力（ステップ応答）は ジョイスティックと比べ, 遅れ時間, 整定時閒, オー バーシュートの值で 1.5 から 2 倍程度であることがわ かる. また，呼気については吸息圧值（負圧）の方が 応答遅れなど調整能力の点で多少劣るここがわかる.

2.3 周波数応答による呼気圧調整能力の検証 前 章では呼気圧を直接入力とするのではなく，その積分 值を入力として用いることを提案し，手動のジョイス ティック操作と比較した. その結果, ジョイスティッ クの場合より多少性能が劣るものの, 入力装置として 使用できそうであることがわかった.

この呼気圧入力のインタフエースを車椅子での操縦 に利用することを考える.このとき, 歩道や廊下に沿っ ての移動など，移動すべき目標軌跡はあらかじめ，あ る程度わかっていることが多い．従ってランダムに与 えたステップ応答の性能を調べるだけでは十分でない と考えられる.

そこで，ディスプレイ上に目標軌道として正弦波を あらかじめ表示し，次に，マーカーがその目標正弦波 に沿って移動するようにする．このとき呼気圧を積分 したものを縦軸の位置として表示し，この位置がマー カーで示した目標軌道にできるだけ追従するように被 験者は呼気圧を調整する. 目標軌道の周波数を変えて この呼気圧積分值の調整能力を調べた.

目標入力を正弦波としたときの典型的な応答の様子 を図 4 に示す.この応答実験を異なつた周波数で複数 回おこない，周波数応答特性を調べた．この結果を図 5 に示す．比較のために手動によるジョイスティック 


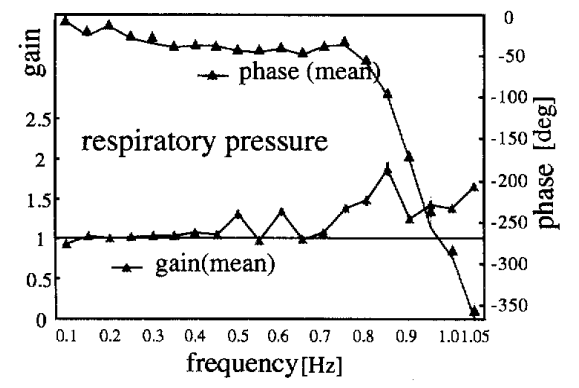

Fig. 5 Frequency response of respiratory pressure

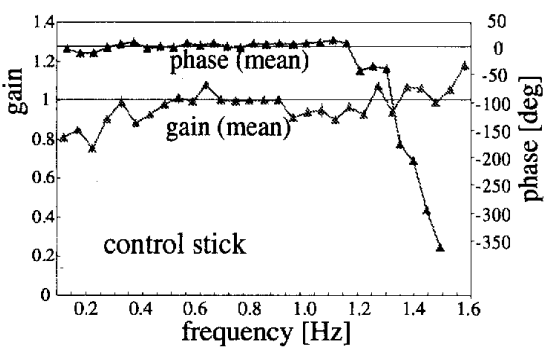

Fig. 6 Frequency response of control stick

の場合の周波数応答を図 6 に示す.これらの周波数応 答は 1 名の被験者の 5 回の試行の平均の值を用いて 描いている. 図に示すように呼気圧では $0.9 \mathrm{~Hz}$ 程度, ジョイスティックでは $1.2 \mathrm{~Hz}$ 程度までの応答が可能で あること，また，呼気圧はジョイスティックに比べて 応答速度が多少劣るものの, 実時間アナログ入力が可 能であることがわかる.

2.4 積分ゲインの影響 これまで示したように 呼気圧をそのまま用いるのではなく，その積分值を用 いて入力值とすることで定常特性にすぐれた入力が可 能となるが, その積分ゲインによって入力装置として の性能が大きく変化する. そこで, 積分ゲインの值に より, ステップ応答での反応遅れ時間 $T_{d}$, 最大行き過 ぎ量 $V_{o v}$, 過渡応答面積誤差 $S_{d e v}$ (図 3 参照) がどの ようになるかを調べた。

種々の積分ゲイン $k_{i}$ によりステップ応答をおこな い, $T_{d}, V_{o v}, S_{d e v}$ をプロットしたものを図 7 に示す.上 が呼息, 下が吸息の場合である.この結果により，反 応速度 $\left(T_{d}\right)$ と応答精度 $\left(V_{o v}, S_{d e v}\right)$ はトレードオフの関 係にあり，一般に積分ゲインが大きいと応答精度が劣 化し，小さいと反応速度が劣化することがわかる．ま た，呼息と吸息においては，吸息側の性能值が多少劣 るものの, 積分ゲインに対する傾向はほぼ同じであっ た.この結果から適切な積分ゲインにここでは*印で 示す付近）を設定すればほぼ両方満足する性能が得ら れることがわかる.
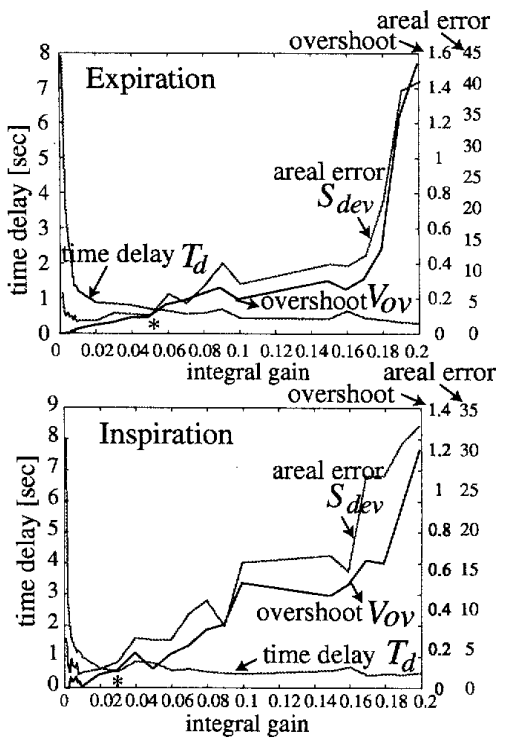

Fig. 7 Performance of step response for integral gains

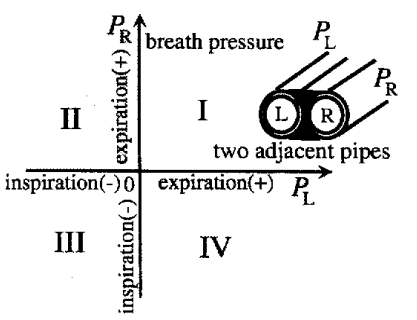

Fig. 8 Possible region for the input of 2-DOF case

\section{2 自由度の入力装置と車椅子操縦}

これまでは呼気圧を用いた 1 自由度の実時間アナ ログ入力装置の基本性能を調べた. しかし, 電動車椅 子においてジョイステイックと同様な操作を考える場 合, 2 自由度の実時間アナログ入力が望ましいと考え られる。

人の口による呼気圧調整能力を考光る場合, 例えば 多くの管楽器では入力口部は一つであり， 2 自由度の 入力は困難に思える. しかし，二段のハーモ二力の場 合は上下に隣り合った入力口部があり, 同時に $2 つ の$ 入力口部を用いて微妙な音を生成できる. なお, 左右 の隣接部では音が混じらないように”吹く”, "吸う”で 音を出す仕組みであり, 左右では同時には音を生成で きない. 従って, 例えば $2 \supset$ つ力口部 $(L$ と $R)$ が 隣接している場合は両方が吹く（正圧）か両方が吸う (負圧)ことのみ，すなわち図 8 でI と III の領域しか 圧力設定できない. 図は横軸を左の管からの呼気圧值, 縦軸を右の管からの呼気圧值としたものである.

ジョイスティックと同样なアナログ入力装置という 意味からは，II と IV の領域を使用できないことは欠 

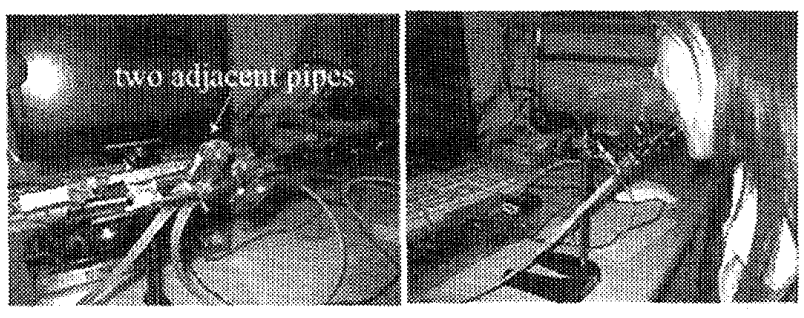

Fig. 9 Two adjacent pipes as an input device

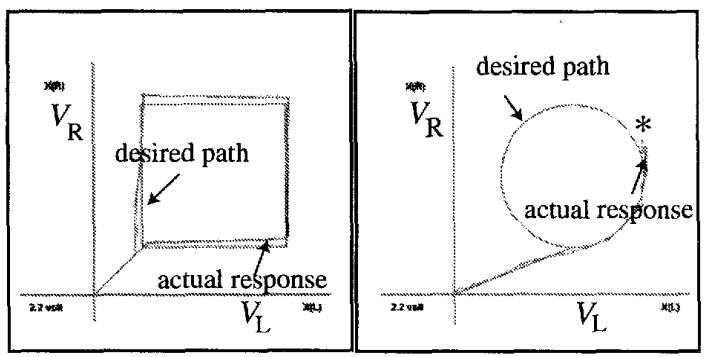

Fig. 10 Tracking ability using the two adjacent pipes

点になるが，I の領域の中だけでも 2 自由度アナログ 入力が可能であるとも考えられる. そこで領域 I 内に おいてどの程度 2 自由度呼気圧調整が可能かを調べる.

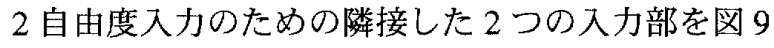
に示すように並べて固定する．口をわずかに左右に移 動させながら呼気圧を調整する，横軸に $L$ 側呼気圧を 積分した值 $V_{L}$ をとり，縦軸に $R$ 側呼気圧を積分した 值 $V_{R}$ をとる. 目標図形（正方形と円）をディスプレ イ上で示し，呼気圧調整により目標軌跡をたどれるか 調べたものを図 10 に示す，正方形の方は $L, R$ 独立に 正の呼気圧と負の呼気圧を入力すれば実現できる.し かしながら，右図の円の方は*印を付けたあたりから $R$ は正で $L$ は負の呼気圧を入力する必要があるため, ここで用いている 2 つ並べた吹き口を用い，左右の呼 気圧力を両方積分する方法ではこの軌跡は実現できな かった.

そこで，2つの入力口部を同時に使用せず，別々に 使用することを考える. このとき， 口唇部の動作をで きるだけ小さくする 2 自由度入力として図 11 に示す, パイプを段差をつけて上下 2 段にしたものを試作し た. 上下の入力圧力をどのように利用するかは種々考 えられるが，いくつかの方法を試したのち，違和感な く入力できるものとして上部パイプのみ入力のとき （図 11A）泪転角速度の指令，両方同時に入力する とき（図 11B）は前進（後退）速度の指令とした．口 から離すと回転角速度は 0 となるためその移動方向を 維持する．また移動速度はそのときの值を保つことと し，危険回避のために強く吸う（負の呼気圧）場合は 緊急停止するよう指令を与えることにした。

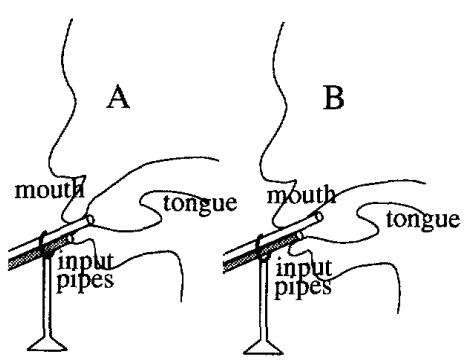

Fig. 11 Input method by up-and-down pipes

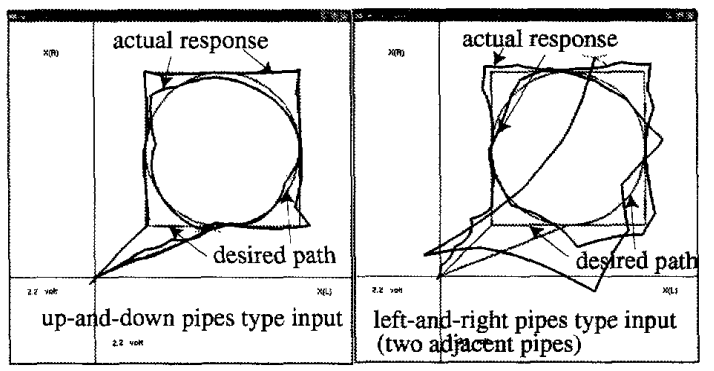

Fig. 12 Tracking ability for the improved input device

このとき, 電動車椅子の回転速度 $\dot{\theta}$, 前進速度 $v$ は下 部パイプが大気在のとき, すなわち $\left|p_{L}(t)-p_{0}\right|<p_{\text {noize }}$ のとき

$$
\begin{aligned}
\dot{\theta} & =k_{\omega} g\left(p_{U}(t)-p_{0}\right) \\
\nu & =v_{0}
\end{aligned}
$$

下部パイプおよび上部パイプに呼気圧が印加されてい るとき

$$
\begin{aligned}
& \dot{\theta}=0 \\
& v=v_{0}+k_{i} \int_{0}^{t} g\left(p_{U}(t)+p_{L}(t)-p_{0}\right) d t
\end{aligned}
$$

ここで, $p_{U}(t), p_{L}(t)$ は上部および下部パイプの呼気 圧值である．ただし，負の強い呼気圧の場合は

$$
\begin{gathered}
p_{U}(t)-p_{0}<-p_{\max } \text { or } p_{L}(t)-p_{0}<-p_{\max } \\
\text { then } v=0
\end{gathered}
$$

とする. このときの電動車椅子の左右車輪速度 $\omega_{L}, \omega_{R}$ 指令值は運動学関係より

$$
\left(\begin{array}{c}
\omega_{L} \\
\omega_{R}
\end{array}\right)=\left(\begin{array}{cc}
\frac{r}{2} & \frac{r}{2} \\
\frac{r}{l} & -\frac{r}{l}
\end{array}\right)^{-1}\left(\begin{array}{c}
v \\
\dot{\theta}
\end{array}\right)
$$

で与える.ここで $r, l$ は車椅子車輪半径と車輪間距離 をそれぞれ表す。

この制御方法を用い，正方形と円形の目標軌跡を与 えたときの応答結果例を図 12 左に示す. 左図は上下 2 段パイプにより呼気圧を調整した場合，右図は比較 


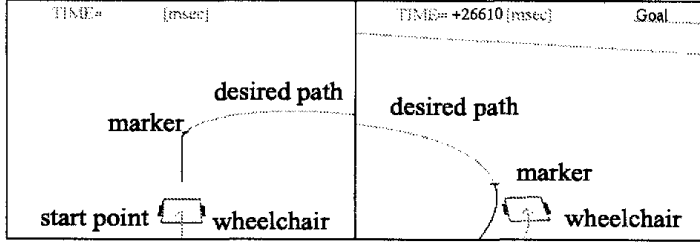

Fig. 13 Motored wheelchair simulator using respiratory pressure input method

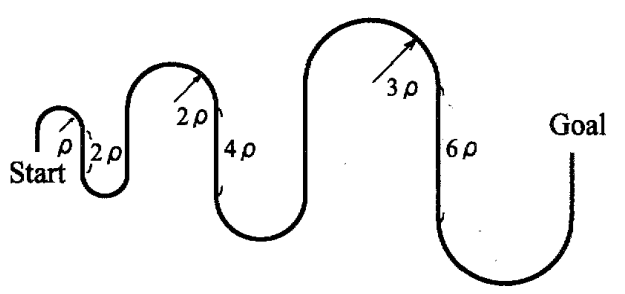

Fig. 14 Desired path for the tracking experiment by simulator

のため図 9 で示す 2 本のパイプを左右に隣接したもの を用いて上記と同様に呼気圧調整した場合を示す．上 下 2 段パイプにより呼気圧を調整する場合は，より良 い性能で軌跡追従が可能であることがわかった.

この上下 2 段パイプによる入力方法により, 入力イ ンタフエース利用者の視点から電動車椅子操縦可能な シミュレータを作成し, 実際の呼気圧入力インタフェー スを用いて軌道追従実験をおこなった．このときのシ ミュレータ画面を図13に示す.

追従すべき目標経路は図 14 に示す円弧と直線から なる経路を与えた. 被験者はシミュレータ画面に示し た目標経路を見ながら, 経路上を移動するマーカーに できるだけ沿うように呼気圧を調整しながら電動車椅 子を操縦する. このとき, 経路上の追従マ一カーの速 度を変化させながら, 呼気圧調整による追従性能を手 動ジョイスティックの場合と比較した．追従性能を評 洒するための指標として以下の, 目標軌跡からの偏差 面積評価 $H_{e r r}$ と追従用マーカーからの距離偏差 $L_{e r r}$ を 用いて比較する.

$$
\begin{aligned}
H_{\text {err }} & =\frac{S}{l_{\text {path }}} \\
L_{\text {err }} & =\frac{\int_{0}^{T_{\text {end }}} l(t) d t}{T_{\text {end }}}
\end{aligned}
$$

ここで $S$ は図 15 灰色領域に示す目標軌跡之追従軌跡 の偏差面積, $l_{\text {pat }}$ は目標経路長, $T_{\text {end }}$ は追従終了時間, $l(t)$ は時刻 $t$ での車椅子中心位置と追従用マーカーと の距離を表す，提案した 2 段重ね呼気圧入力口部を用

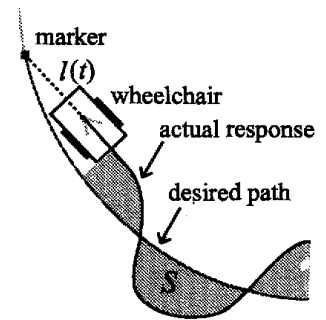

Fig. 15 Deviation from desired path and marker point

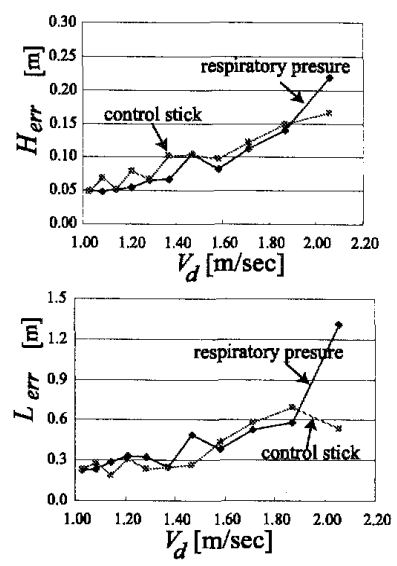

Fig. 16 Comparison of tracking ability using respiratory pressure and control stick

いた車いす操縦制御方式と, 手動ジョイステイックに よる操縦方式による追従実験結果を図 16 に示す。こ の図は横軸を追従目標マーカ一の移動速度とし，上の 図は面積評価値 $H_{e r r}$, 下の図は偏差距離評価値 $L_{e r r}$ を, 呼気圧インターフェースの場合とジョイスティックの 場合で比較したものである. 図から，2つのインター フェース手法ともに，目標移動速度が大きくなると， 追従性能は劣化しているが，呼気圧による方法はジョ イスティックによる方法とほぼ同等の性能を有してい ることがわかる.

\section{4. 結 言}

本研究は，呼吸機能障害を併発していない場合の四 肢障害者のための，電動車椅子操縦を想定したアナロ グ入力インターフェースとして，呼気圧を用いる方法 を検討した．結果をまとめると以下のようになる.

- 1 自由度の呼気圧による入力インターフェースを 試作し，予測できない目標軌跡に追従する場合 の呼気圧調整応答実験（ステップ応答実験）をお こなった.この結果, 呼気圧の值を直接用いない でその積分值を利用すれば，呼気圧による入力方 法は手動ジョイスティックと同様に入カインター 
フェースとして利用可能であることがわかった. また，正圧 (呼息) の方が負圧（吸息）の方より 調整能力がすぐれていることがわかった。

- 呼気圧積分值による, 提案入力手法の周波数特性 を調ベた。この結果からもジョイスティックの場 合と比較してまずまずの速応性能を有することが わかった．また，呼気圧を積分するときの積分定 数についてその最適值を決める方法を示した.

・電動車椅子操縦を想定し，呼気圧による 2 自由度 入力の方法を検討した. 2 自由度すなわち 2 本の 入力パイプを同時に入力する方法では，自在な指 令值生成怯困難であることがわかった。そこで, 段差を付けた上下 2 段のパイプによる入力部を 作成し，車椅子の移動速度亡，回転速度指令值を 別々に入力する方法を提案した．この方法を用い て電動車椅子の動作シミュレーション実験をおこ ない，呼気圧による電動車椅子操縦が可能である ことがわかった。

今後，安全性を十分考慮しながら，実際の電動車椅 子の操采実験をおこなこと，また，健常者でなく，四 肢障害者による操縦実験をおこなうことを予定して いる.

\section{文献}

(1) Foundation of Social Development for Senior Citizens ed., Handbook (f Nursing-Care Equipments (in Japanese), (1995), pp.64-65, Gyousei Co., Ltd.

(2) Ito, E., et. al., Various Ideas for the Application of Environmental Control System (in Japanese), Proc. of the 7th Rehabilitations Engineering Corference, (1992), pp.83-86.

(3) Craig, A., Moses, P., Tran, M.Y., McIsaac, P. and Kirkup, L., The Effectiveness of a Hands-Free Environmental Control System for the Profoundly Disabled, Arch Phys Med Rehabil, Vol 83, (2002), pp.1455-1458.
(4) Miyazaki, S., High-Speed Personal Computer Input Interface Requiring No Limb Movements, Journal of Biomechanisms, No.17, (2004), pp.227-234.

(5) Lotte N.S. and Andreasen S., An Inductive Tongue Computer Interface for Control of Computers and Assistive Devices, IEEE Tran. on Biomedical Engineering, Vol.53, No.12, (2006), pp.2594-2597.

(6) Moon, I., Lee, M., Ryu, J. and Mun, M., Intelligent Robotic Wheelchair with EMG-, Gesture-, and Voicebased Interfaces, Proc. of the 2003 IEEE Int. Corf. on Intelligent Robots and Systems, (2003), pp.3453-3458.

(7) Kuno, Y., Shimada, N. and Shirai, Y., A Robotic Wheelchair Based on the Integration of Human and Environmental Observations, Robotics and Automation Magazine, MARCH, (2003), pp.26-34.

(8) Harada, S., Landy, J.A., Malkin, J., Li, X. and Bilmes, J.A., The Vocal Joystick: Evaluation of voice-based cursor control techniques for assistive technology, Disability and Rehabilitation: Assistive Technology, Vol.3, (2008), pp.22-34.

(9) Gounden, P., Static respiratory pressures in patients with post-traumatic tetraplegia, Spinal Cord, Vol.35, (1997), pp.43-47.

(10) Kera, T., Characteristics of Respiratory Muscle, Journal of Physical Therapy Science, Vol.16, No.4, (2001), pp.231-238.

(11) Alvarez, S.E., Peterson, M. and Lunsford, B.R., Respiratory Treatment of the Adult Patient with Spinal Cord Injury, Physical Therapy, Vol.61, No.12, (1981), pp.1737-1745.

(12) Cao, F. and Yamamoto, M., A Man-Machine Interface Device for Disabilities Using Breath Pressure, Proc. $c$ f the 2006 JSME Corference on Robotics and Mechatronics, (2006), pp.1P1-A20.

(13) Cao, F. and Yamamoto, M., Study of a Two-dimensional Analogue Input Device for Human Crae Use, Proc. of the 24th Annual Corference of the Robotics Society of Japan, (2006), pp-1117.

(14) Sugi, H., Physiology for Human Body (in Japanese) Nanedo Co., Ltd., (2003), pp.341-342.

(15) Inooka, H., Ishihara, T. and Ikeura, R., Intelligent Control System, Koudansha Scientific Co., Ltd., (2000), pp.139. 140. 